\title{
Sistem Pendukung Keputusan Pemilihan Siswa Teladan Menggunakan Metode Simple Additive Weighting (SAW) Pada SMK Telkom Purwokerto
}

\author{
M. Yoka Fathoni ${ }^{[1]^{*}}$, Darmansah ${ }^{[2]}$, Dwi Januarita ${ }^{[3]}$ \\ Sistem Informasi [1], [2], [3] \\ Institut Teknologi Telkom Purwokerto [1], [2], [3] \\ Purwokerto, Indonesia \\ myokafathoni@ittelkom-pwt.ac.id ${ }^{[1]}$, darmansah@ittelkom-pwt.ac.id ${ }^{[2]}, \underline{\text { dwijanuarita@ittelkom-pwt.ac.id }}{ }^{[3]}$
}

\begin{abstract}
Abstrack - The process of determining model students is a process of assessing students from various aspects determined by the school. Determining the best students at SMK Telkom Purwokerto is very important to increase students' enthusiasm for learning, because awards will motivate student achievement. Determination of fast and accurate calculations requires a system that can handle decision-making management to produce the best students. The Simple Additive Weighting (SAW) method is a method that can be used to determine student achievement. The case study was conducted at SMK Telkom Purwokerto. This information system for determining quality students is expected to be used as a tool at SMK Telkom Purwokerto. With this system, schools can easily select criteria and determine the best students in the school.
\end{abstract}

Keywords-Decision Support System, Model Student, Simple Additive Weighting (SAW)

\begin{abstract}
Abstrak- Proses penentuan siswa teladan merupakan proses penilaian siswa dari berbagai aspek yang ditentukan oleh sekolah. Penetapan siswa terbaik di SMK Telkom Purwokerto sangat penting untuk meningkatkan semangat belajar siswa, karena penghargaan akan memotivasi prestasi belajar siswa. Penentuan perhitungan yang cepat dan akurat memerlukan suatu sistem yang dapat menangani manajemen pengambilan keputusan untuk menghasilkan siswa terbaik. Metode Simple Additive Weighting (SAW) merupakan metode yang dapat digunakan untuk mengetahui prestasi belajar siswa. Studi kasus dilakukan di SMK Telkom Purwokerto. Sistem informasi penentuan siswa berkualitas ini diharapkan dapat digunakan sebagai sarana di SMK Telkom Purwokerto. Dengan sistem ini, sekolah dapat dengan mudah memilih kriteria dan menentukan siswa terbaik di sekolah tersebut.
\end{abstract}

Kata Kunci- Sistem Pendukung Keputusan, Siswa Teladan, Simple Additive Weighting (SAW)

\section{Pendahuluan}

Kejuruan merupakan salah satu jenis pendidikan di Indonesia. Lulusan dari sekolah kejuruan perlu memiliki cukup motivasi untuk masuk ke lingkungan kerja baik sebagai karyawan atau sebagai pengusaha [1]. SMK Telkom purwokerto merupakan salah satu sekolah menengah kejuruan di Kota purwokerto yang beralamatkan di Jalan DI. Panjaitan No. 128 mempersiapkan peserta didiknya agar mempunyai peserta didik yang ungul dan professional dalam mengisi formasi yang ada nantinya pada dunia insustri/ usaha/ pemerintahan sebagai tenaga kerja tingkat menengah sesuai dengan kompetensi keahliannya, sehingga untuk tercapai tujuan tersebut sekolah merupakan sebuah lembaga pendidikan yang mengembangkan berbagai potensi potensi yang dimiliki oleh peserta didik. Salah satu kegiatan yang di lakukan sekolah ialah dengan cara melalui pemilihan siswa yang teladan berdasarkan nilai akademik dan non-akademik.

Telkom Schools SMK Telkom Purwokerto dibangun pada 30 Januari 1993, berdasarkan surat Kepala Kantor Wilayah Depdikbud Propinsi Jawa Tengah tentang persetujuan pendirian sekolah swasta yang diselenggarakan oleh Yayasan Sandhykara Putra Telkom dan diresmikan oleh Menparpostel Bapak Soesilo Soedarman.

Pemilihan peserta didik yang teladan di SMK Telkom Purwokerto saat ini masih dilakukan secara manual untuk menentukan peserta didik yang berhak mendapatkan gelar siswa teladan, walaupun kriteria-kriteria penilaian dan kisaran skor penilaian telah ditentukan, cara tersebut kurang efektif dalam melakukan penilaian keobjektifan karena penilaian terhadap siswa teladan masih bergantung kepada penilaian setiap anggota juri.

Sistem Pendukung Keputusan (SPK) merupakan suatu sistem informasi interaktif yang dapat memberikan suatu informasi, visualisasi serta bisa untuk memanipulasi suatu data [2] . Sistem ini digunakan untuk membantu pengambilan keputusan dalam situasi yang semiterstruktur dan situasi yang tidak terstuktur, dimana tidak seorangpun tahu secara pasti bagaimana keputusan seharusnya dibuat. [3] pernah melakukan penerapan dalam teknologi untuk mendapatkan keputusan yang fleksibel yang disebut model grafik agar memudahkan dan mempercepat para praktisi dan peneliti diperlukannya DSS. [4] juga membuat system pendukung keputusan untuk melakukan pertimbangan dalam membeli kendaraan bekas. Menurut [5] Sistem pendukung keputusan memiliki beberapa metode, diantaranya yaitu Analitycal Hierarchy Process (AHP), Simple Additive Weighting (SAW), Weighted Product (WP), Electre, Technique For Others Reference by Similarity to Ideal Solution 
(Topsis).

SAW sering juga dikenal dengan sebutan sebuah metode untuk penjumlahan terbobot, cara atau metode ini sering di gunakan dalam menghadapi situasi untuk pengambilan sebuah kebijkan. Metode ini digunakan karena bias memilih solusi yang paling baik dari beberapa solusi berdasarkan kriteria yang ditetapkan, kriteria bersifat dinamis nilai bobotnya dapat diubah sesuai keinginan user.

Penentuan siswa berprestasi dengan beberapa kriteria akan memakan banyak waktu untuk perhitungannya, disinilah muncul kebutuhan akan sistem informasi penentuan siswa berprestasi untuk menangani pengelolaan nilai dan menentukan siswa berprestasi secara cepat dan akurat dari beberapa kriteria yang ada.

\section{TINJAUAN PUSTAKA.}

Pengelompokan data yang biasanya digunakan yaitu dengan metode k-Means dan Fuzzy C Means (FCM) yang biasa digunakan selain metode SAW[6]. Menurut [7] pada penelitian dengan judul Sistem Pendukung Keputusan Penerimaan Siswa Baru Dengan Metode Simple Additive Weighting (SAW). Hasil dari penelitian ini berupa website SPK yang menggunakan metode SAW, dalam proses pengaplikasiannya sistem yang dibuat menggunakan beberapa komponen yaitu server dan fasilitas untuk koneksi internet. Proses penerimaan siswa baru menggunakan beberapa kriteria yaitu nilai Ujian Nasional (UN), Nilai Prestasi, Tes Khusus, Asal Sekolah, Nilai Lingkungan, dan Nilai Kemaslahatan. Sistem yang dibuat bisa memberikan suatu hasil yang lebih baik ketika menggunakan Excel.

Pada penelitian [8] dengan judul yaitu Sistem Pendukung Keputusan Pemilihan Dosen Berprestasi di STMIK Tasikmalaya Menggunakan Metode Simple Additive Weighting (SAW). Dalam pemilihan ini, STMIK Tasikmalaya membentuk tim khusus, pada penelitian ini keteria yang di pakai adalah Penilaian Mahasiswa, Penilaian Dosen sejawat, Pengabdian kepada Masyarakat, dan Jabatan Akademik. Dalam penelitiannya perancangan sistemnya menggunakan diagram arus data, dan teknik perancangan basis datanya menggunakan ERD. Hasil dari penelitian ini adalah metode yang di pakai bias mengatasi permasalahan dalam penentuan dosen berprestasi.

Adapun penelitian [9] dengan judul Penentuan Peserta Lomba Kompetensi Siswa Menggunakan Simple Additive Weighting (SAW). Sistem yang dibangun bias memberikan rekomendasi keputusan yang sesuai, dengan 6 kriteria yaitu peringkat rangking, nilai rata-rata raport, nilai uji kompetensi, nilai pelajaran, nilai etika, hasil pengalaman LKS sebelumnya. Metode yang digunakan dalam penelitian tersebut adalah metode SAW, dengan menggunakan metode ini hasil seleksi mampu berjalan dengan ketat. Pada penelitian lain nya tahap desain sistem dengan model berbagi cerdas menggunakan Big Data untuk pencapaian kreatif mahasiswa di era internet [10].

Metode SAW juga digunakan pada masa pandemi setelah terjadinya COVID- 19, ada perubahan signifikan dalam statistik ekonomi, ini adalah dipengaruhi oleh kegiatan ekonomi yang tidak stabil dibandingkan dengan sebelum masa pandemi[11]. [12] Membuat penelitian penurunan populasi tingkat ekonomi rakyat yang disebabkan oleh covid-19 dengan tujuan untuk membantu perguruan tinggi dalam menentukan mahasiswa yang berhak mendapatkan bantuan biaya kuliah tunggal (UKT) dengan Algoritma K-Nearest Neighbor (KNN) dan SAW. Kemudian terdapat juga penelitian [13] menentukan penerimaan beasiswa berdasarkan kriteria yang melalui proses seleksi sehingga mendapatkan bobot kriteria yang berbeda. Pada penelitian tersebut menggunakan metode SAW, dengan system ini dapat meminimalkan kesalahan menentukan calon penerima beasiswa siapa yang unggul. Hal serupa juga pernah dilakukan pada penelitian [14] dengan menggunakan SAW dan Metode Weighted Product diimplementasikan sebagai solusi untuk mendukung sistem rekomendasi beasiswa.

Metode Simple Additive Weighting (SAW) didasarkan pada rata-rata. Metode SAW sering digunakan sebagai metode penilaian yang berkaitan dengan keputusan dengan berbagai atribut [15]. Skor evaluasi dihitung untuk setiap alternatif dengan mengalikan nilai skala yang diberikan pada alternatif atribut dengan bobot relatif penting yang diberikan langsung oleh pengambil keputusan diikuti dengan menjumlahkan produk untuk semua kriteria.

\section{Metodelogi Penelitian}

Berikut adapun alur pada penelitian ini adalah sebagai berikut ini :

1) Identifikasi Masalah

Tahap ini peneliti dilakukan untuk mengetahui kendala-kendala dalam penentuan siswa teladan di SMK Telkom Purwokerto seperti pengolahan data siswa masih dilakukan secara manual dengan menggunakan Microsoft.Excel.

2) Pengumpulan data

Pada tahapan ini, peneliti melakukan pengumpulan data untuk memperoleh informasi seputar permasalahan yang di angkat dalam penelitian ini, antara lain yang peneliti pakai adalah studi literatur, dilakukan pengumpulan informasi mengenai penelitian serupa melalui jurnal ilmiah, jurnal hasil penelitian dan buku yang diperlukan dalam penelitian.

3) Analisis Data

Dari tahapan pengumpulan data yang peneliti lakukan, maka hasil dari pengumpulan data tersebut di gunakan untuk dasar pembuatan system yang mampu menyelesaikan permasalahan yang sedang di teliti.

4) Perancangan Sistem

Pada tahapan ini peneliti membuat sebuah rancangan sistem yang terinci berdasarkan dari hasil analisa data yang peneliti dapatkan pada tahapan sebelumnya. Rancangan system yang akan dibuat harus mampu menyelesaikan masalah yang sedang diteliti.

5) Pembuatan Sistem

Pada tahap proses pembuatan sistem pendukung keputusan pemilihan siswa teladan yaitu dengan menggunakan coding sistem sehingga menghasilkan sebuah sistem yang siap dioperasikan.

6) Pengujian Sistem

Tahap ini untuk menguji sistem yang telah dibuat, 
tahapan ini untuk mengetahu apakah sistem yang dibuat mampu menyelesaikan masalah dan berfungi dengan baik. Ketika dengan adanya pengujian sistem ini peneliti mampu mengetahui jika terjadi kesalahan pada sistem dengan menggunakan metode perangkat lunak.

Pada bab ini, pengujian sistem pendukung keputusan menggunakan metode pembobotan Simple Additive Weighting $(S A W)$, mulai dari menganalisis masalah hingga kriteria pembobotan.: [4]

1) Menentukan kriteria-kriteria yang akan dijadikan acuan dalam pengambilan keputusan, yaitu $\mathrm{C}_{\mathrm{j}}$.

2) Menentukan rating kecocokan setiap alternatif pada setiap alternatif pada setiap kriteria.

3) Membuat matriks keputusan berdasarkan kriteria $\left(\mathrm{C}_{\mathrm{j}}\right)$, kemudian melakukan normalisasi matriks berdasarkan persamaan yang disesuaikan dengan jenis atribut (atribut keuntungan ataupun atribut biaya) sehingga diperoleh matriks ternormalisasi R.

4) Hasil akhir diperoleh dari proses perankingan yaitu penjumlahan dari perkalian matriks ternormalisasi $\mathrm{R}$ dengan vektor bobot (W) sehingga diperoleh nilai terbesar yang dipilih sebagai alternatif terbaik $\left(\mathrm{A}_{\mathrm{i}}\right)$ sebagai solusi pada persamaan (1) dibawah ini:

$r_{i j}=\left\{\begin{array}{lc}\frac{x_{i j}}{\max x_{i j}} & \text { Jika } \mathrm{j} \text { adalah atribut keuntungan (benefit) } \\ \frac{\min x_{i j}}{x_{i j}} & \text { Jika } \mathrm{j} \text { adalah atribut biaya (cost) }\end{array}\right.$

Dengan :

$\mathrm{r}_{\mathrm{ij}}$ : Rating kinerja ternormalisasi dari alternatif $\mathrm{A}_{\mathrm{i}}$ pada atribut $\mathrm{C}_{\mathrm{j}}$;

$\mathrm{i}=1,2, \ldots, \mathrm{m}$ dan $\mathrm{j}=1,2, \ldots, \mathrm{n}$. (m dan $\mathrm{n}$ merupakan banyaknya kriteria dan alternatif).

$\mathrm{X}_{\mathrm{ij}}$ adalah rating kecocokan pada $\mathrm{A}_{\mathrm{i}}$ ddan $\mathrm{C}_{\mathrm{j}}$.

Nilai preferensi disajikan pada persamaan (2) dibawah ini :

$V_{i}=\sum_{j}^{n}=1 w_{j} r_{i j}$

Dengan :

$\mathrm{r}_{\mathrm{ij}}$ adalah rating kinerja ternormalisasi dari alternatif $\mathrm{Ai}$ pada atribut $\mathrm{C}_{\mathrm{j}}$;

$\mathrm{W}_{\mathrm{j}}$ adalah bobot dari masing-masin kriteria.

Nilai $V_{i}$ yang lebih besar mengindikasikan bahwa alternatif $\mathrm{A}_{\mathrm{i}}$ lebih terpilih.

\section{PERANCANGAN DAN DESAIN}

Berikut ini tampilan flowchart dari metode SAW untuk penentuan siswa berprestasi yang terdapat pada gambar berikut

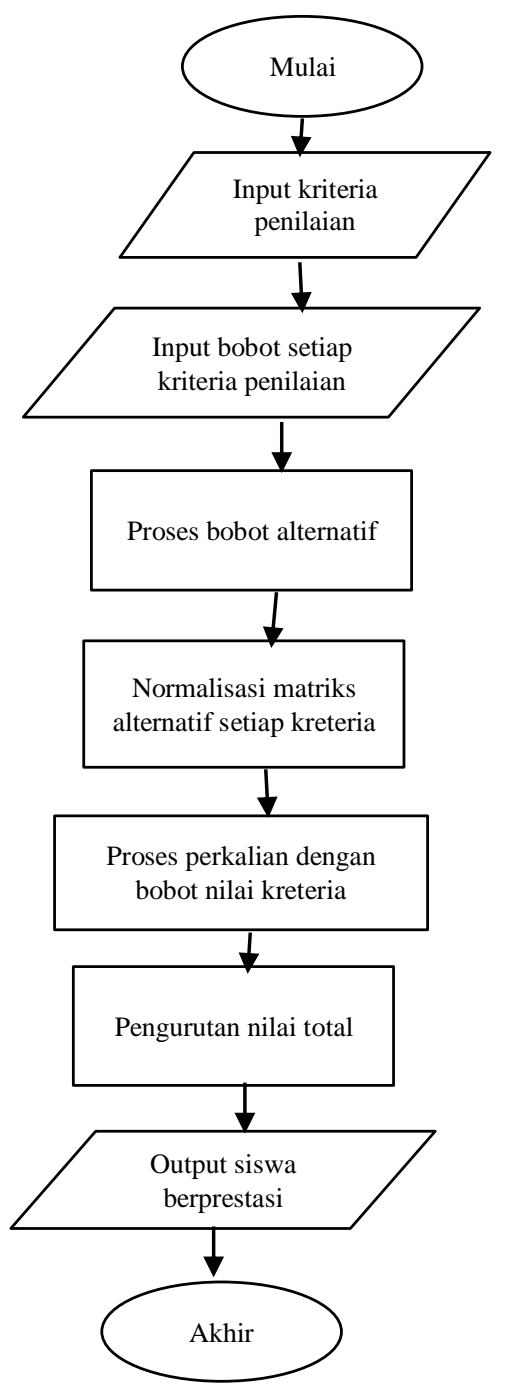

Gambar 1. Flowchart Metode SAW

Pada bagian perancangan sistem yang akan diusulkan dibuat dengan menggunakan perancangan UML (Unified Modeling Language). [16] UML merupakan salah satu pemodelan yang menjadi standar dalam berbagai bidang pengembangan perangkat lunak sebagai media untuk mengambarkan sebuah system perangkat lunak. sedangkan untuk pembutan perangkat lunaknya menggunakan Delphi XE2 dan $M y S Q L$ sebagai penyimpanan data. 


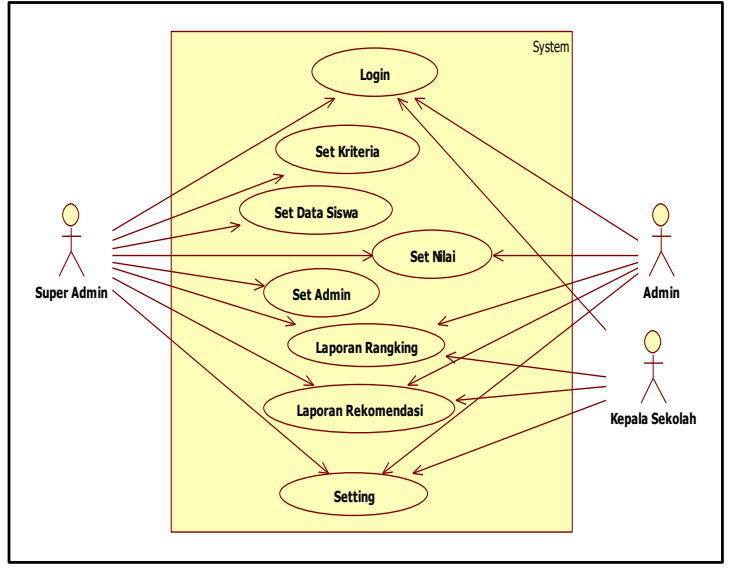

Gambar 2. Use Case Diagram

Gambaran secara umum sistem yang berjalan pada aplikasi SPK pemilihan siswa teladan menggunakan metode SAW. Login pada aplikasi untuk dapat mengakses sistem, verifikasi hak akses user, masuk ke sistem. Proses perangkingan menggunakan perhitungan metode SAW, mulai dari menentukan kriteria sampai proses akhir menghasilkan perangkingan. Output yang dihasilkan adalah perangkingan berupa laporan, dimana nilai akhir tertinggi merupakan alternatif terbaik.

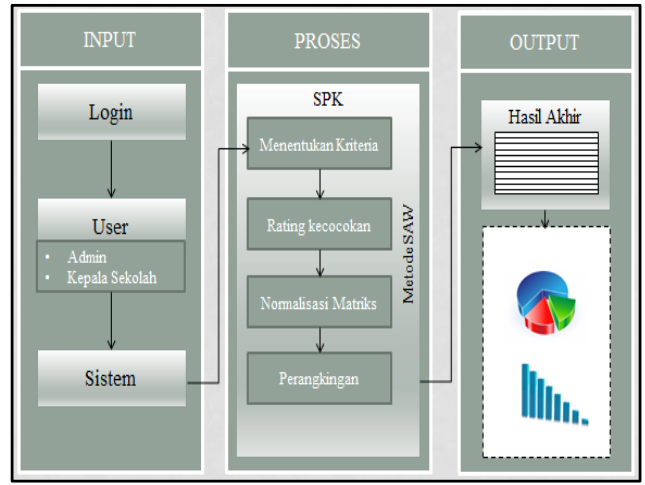

Gambar 3. Kerangka Sistem Informasi

\section{Hasil dan Pemabahasan Penelitian}

Hasil penelitian dari pembuata aplikasi SPK pemilihan siswa teladan pada SMK Telkom Purwokerto sebagai berikut :

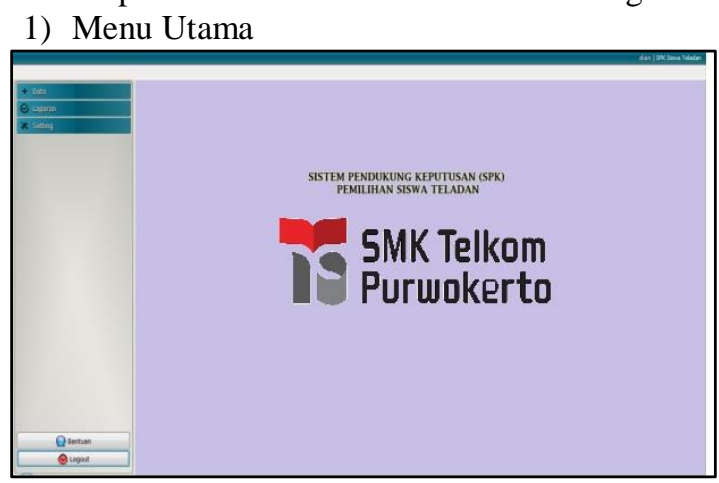

Gambar 4. Menu Utama
Halaman menu utama yang pertama ada ketika pengguna berhasil masuk,pada halaman ini terdapat beberapa menu yaitu menu data, menu laporan, dan menu setting.

2) Menu Set Kriteria

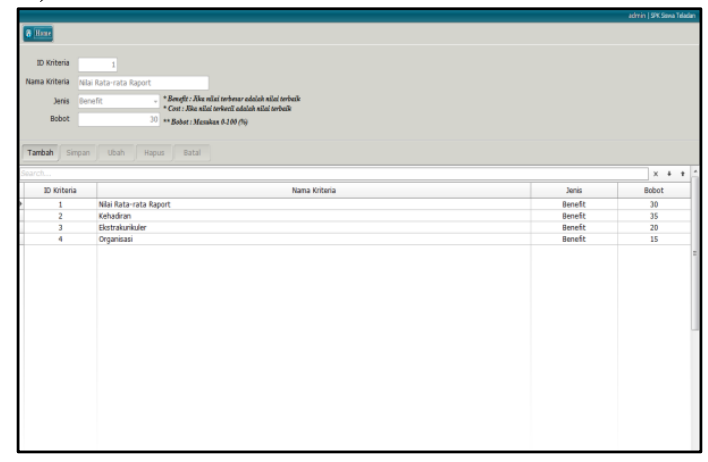

Gambar 5. Menu Set Kriteria

Pada menu ini untuk mengolah data kriteria yang berguna dalam menentukan kriteria apa saja yang akan digunakan dalam pemilihan siswa teladan metode SAW. Menu ini hanya dapat diakses oleh super admin. Berikut adalah gambar tampilan form set kriteria.

\section{3) Menu Set Data Siswa}

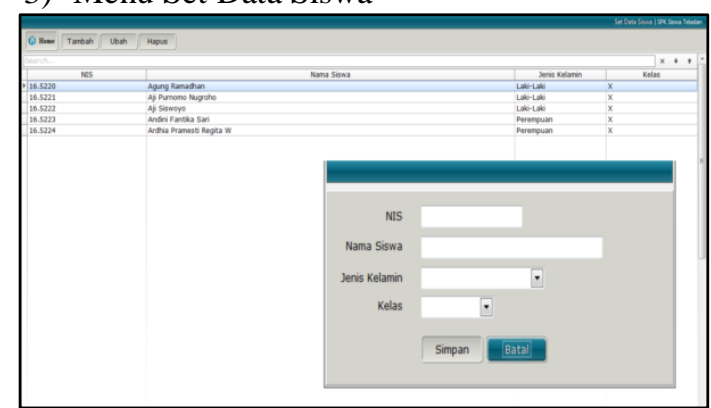

Gambar 6.Menu Set Data Siswa

Pada menu ini digunakan untuk memasukan data siswa yang akan diseleksi, тепи ini hanya dapat diakses oleh super admin.

4) Menu Set Nilai

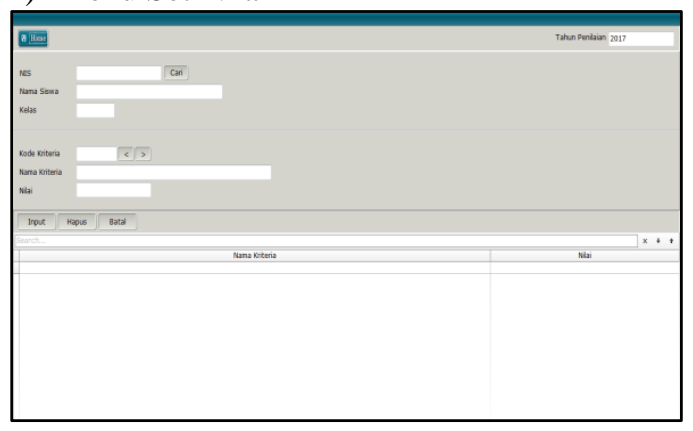

Gambar 7. Menu Set Nilai 
Pada menu ini untuk mengolah nilai masingmasing kriteria dari setiap siswa, yang berguna untuk menentukan bobot kriteria dari data yang diinputkan. Menu ini dapat diakses oleh super admin dan admin. Berikut adalah gambar tampilan form set nilai.

5) Menu Laporan Rangking

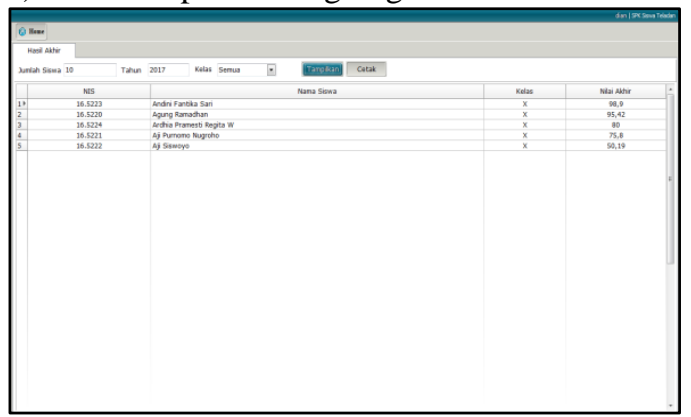

Gambar 8. Menu Laporan Rangking

Halaman ini dapat diakses oleh super admin, admin, dan kepala sekolah, berisi perangkingan siswa berdasarkan peringkat tertinggi sampai terendah. Halaman merupkan sebagai tempat kerja utama untuk melakukan pengolahan data siswa menggunakan metode SAW.

6) Menu Laporan Rekomendasi

Pada menu ini menampilkan laporan rekomendasi siswa teladan berdasarkan tingkatan kelas, dan hanya terdapat data siswa yang memiliki nilai akhir tertinggi pada tiap tingkatan kelas.

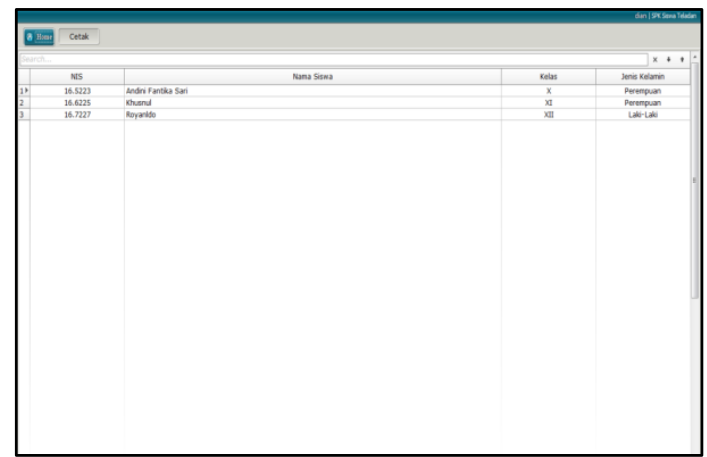

Gambar 9. Menu Laporan Rekomendasi

Berikut ini adalah pembahasan menggunakan metode SAW dalam menentukan siswa berprestasi yaitu sebagai berikut:

1) Perhitungan Metode SAW

Berikut ini merupakan tabel rating kecocokan dari setiap alternatif pada setiap kriteria.
Tabel 1. Nilai Alternatif Setiap Kriteria

\begin{tabular}{|c|c|c|c|c|}
\hline \multirow[b]{2}{*}{ Alternatif } & \multicolumn{4}{|c|}{ Kriteria } \\
\hline & $\begin{array}{l}\text { Nilai } \\
\text { Rata- } \\
\text { rata } \\
\text { Rapor }\end{array}$ & $\begin{array}{l}\text { Keha } \\
\text { diran }\end{array}$ & $\begin{array}{l}\text { Ekstra } \\
\text { kurikuler }\end{array}$ & Organisasi \\
\hline A1 & 80 & 89 & 1 & 1 \\
\hline A2 & 76 & 80 & 1 & 0 \\
\hline A3 & 75 & 65 & 0 & 0 \\
\hline A4 & 79 & 100 & 1 & 1 \\
\hline A5 & 82 & 100 & 0 & 1 \\
\hline
\end{tabular}

Keterangan :

$$
\begin{array}{ll}
\text { A1-5 } & =\text { Alternatif (Siswa) } \\
\mathrm{C} & =\text { Kriteria } \\
\mathrm{W} & =\text { Bobot }
\end{array}
$$

$\mathrm{X}=$ Matriks

Pengambil keputusan memberikan bobot preferensi sebagai berikut :

$\mathrm{W}=\{30 ; 35 ; 20 ; 15\}$

Matriks keputusan dibentuk dari tabel kecocokan sebagai berikut :

$$
\mathbf{X}=\left\{\begin{array}{llll}
80 & 89 & 1 & 1 \\
76 & 80 & 1 & 0 \\
75 & 65 & 0 & 0 \\
79 & 100 & 1 & 1 \\
82 & 100 & 0 & 1
\end{array}\right\}
$$

Normalisasi Matriks X :

$$
\begin{aligned}
\mathrm{r}_{11} & =\frac{80}{\max \{80 ; 76 ; 75 ; 79 ; 82\}}=\frac{80}{82}=0,98 \\
\mathrm{r}_{21}= & \frac{76}{\max \{80 ; 76 ; 75 ; 79 ; 82\}}=\frac{76}{82}=0,93 \\
\mathrm{r}_{31}= & \frac{75}{\max \{80 ; 76 ; 75 ; 79 ; 82\}}=\frac{75}{82}=0,91 \\
\mathrm{r}_{41}= & \frac{79}{\max \{80 ; 76 ; 75 ; 79 ; 82\}}=\frac{79}{82}=0,96 \\
& \mathrm{r}_{51}=\frac{82}{\max \{80 ; 76 ; 75 ; 79 ; 82\}}=\frac{82}{82}=1,00, \mathrm{dst}
\end{aligned}
$$

Dari pengolahan data diatas, maka di dapat hasil ternormalisasi R seperti dibawah ini:

$$
\mathrm{R}=\left\{\begin{array}{llll}
0.98 & 0.89 & 1.00 & 1.00 \\
0.93 & 0.80 & 1.00 & 0.00 \\
0.91 & 0.65 & 0.00 & 0.00 \\
0.96 & 1.00 & 1.00 & 1.00 \\
1.00 & 1.00 & 0.00 & 1.00
\end{array}\right]
$$

Tahapan dari perangkingan dengan pembobotan yang telah ditentukan oleh pengambil keputusan :

$$
\mathrm{W}=\{30 ; 35 ; 20 ; 15\}
$$


Hasil yang diperoleh sebagai berikut :

$$
\begin{gathered}
\text { V1 }=(30)(0,98)+(35)(0,89)+(20)(1,00)+(15)(1,00)= \\
\mathbf{9 5 , 4 2} \\
\text { V2 }=(30)(0,93)+(35)(0,80)+(20)(1,00)+(15)(0,00)= \\
\mathbf{7 5 , 8 0} \\
\text { V3 }=(30)(0,91)+(35)(0,65)+(20)(0,00)+(15)(0,00)= \\
\mathbf{5 0 , 1 9} \\
\text { V4 }=(30)(0,96)+(35)(1,00)+(20)(1,00)+(15)(1,00)= \\
\mathbf{9 8 , 9 0} \\
\text { V5 }=(30)(1,00)+(35)(1,00)+(20)(0,00)+(15)(1,00)= \\
\mathbf{8 1 , 0 0}
\end{gathered}
$$

V4 merupakan alternatif yang direkomendasikan menjadi hasil keputusan karena memiliki nilai lebih tinggi dari nilai lain.

2) Pengujian Validitas

Hasil uji validitas ditampilkan pada Tabel 2 :

Tabel 2. Hasil Pengujian Validitas

\begin{tabular}{|c|c|c|c|}
\hline No & Nama Siswa & $\begin{array}{c}\text { SPK Pemilihan } \\
\text { Siswa Teladan } \\
\text { Metode SAW }\end{array}$ & Manual \\
\hline 1 & $\begin{array}{c}\text { Anggun } \\
\text { Permata Sari }\end{array}$ & 98,9 & 98,90 \\
\hline 2 & Intan Giri & 95,42 & 95,42 \\
\hline 3 & Ayu Silvia & 80 & 81,00 \\
\hline 4 & $\begin{array}{c}\text { Briyan } \\
\text { Gifari }\end{array}$ & 75,8 & 75,80 \\
\hline 5 & $\begin{array}{c}\text { Fathya } \\
\text { Yuanita }\end{array}$ & 50,19 & 50,19 \\
\hline
\end{tabular}

Hasil dari perhitungan manual dan otomatis pada aplikasi memiliki perhitungan yang sama kecuali siswa Ayu Silvia, hasil yang diperoleh melalui perbandingan perhitungan otomatis dan perhitungan secara manual memiliki selisih 1,00 yaitu pada perhitungan manual nilai akhir sebesar 81,00 tetapi pada aplikasi nilai akhir sebersar 80. Selisih perhitungan yang didapat tidak merubah posisi/peringkat siswa, dengan demikian data yang dihasilkan pada aplikasi dinyatakan valid dan berjalan sesuai dengan yang diharapkan.

\section{3) Pengujian Black Box}

Pengujian system yang di bangun menggunakan cara pengujian kotak hitam atau black box testing digunakan untuk melihat hasil dari pengolahan melalui data uji dan mengetahui fungsional dari system yang dibuat dan fungsionalitasnya berjalan, tanpa mengetahui proses yang terjadi dalam system perangkat lunak saat melakukan proses input dan output.

1. Pengujian Form Login

A. Tidak mengisi salah satu field baik username atau password

Hasil yang diharapkan sistem akan menampilkan pesan error, seperti pada Tabel 3 dibawah ini :
Tabel 3. Pengujian Form Login Input Satu Field

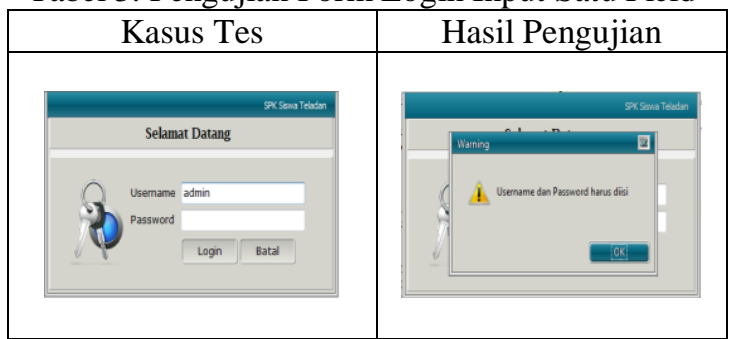

Pada hasil pengujian yaitu dengan tidak mengisi salah satu field maka sistem tidak akan mengakses login dan sistem menampilkan pesan error username dan password harus diisi, oleh karena itu pengujian ini valid.

B. Mengisi username dan password dengan benar

Hasil yang diharapkan sistem mengakses login dan masuk ke halaman utama admin. Seperti pada Tabel 4 dibawah ini

Tabel 4. Pengujian Form Login Benar

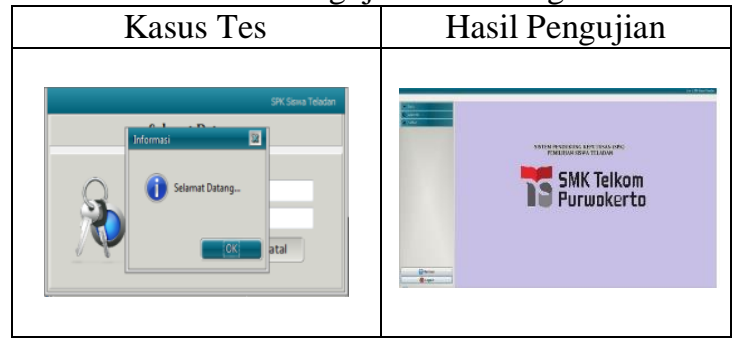

Pada hasil pengujian ketika user atau pemakai system inginputkan kata sandi dan nama pengguna dengan benar, maka sistem dapat mengakses login dan menampilkan halaman utama admin. Maka dari itu pengujian ini dikatakan valid.

2. Pengujian Set Data Siswa

A. Input data siswa (data yang diinputkan tidak lengkap)

Hasil yang diharapkan pada pengujian ini yaitu sistem menampilkan pesan error jika salah satu field blum terisi.

Tabel 5. Pengujian Input Data Siswa Tidak Lengkap

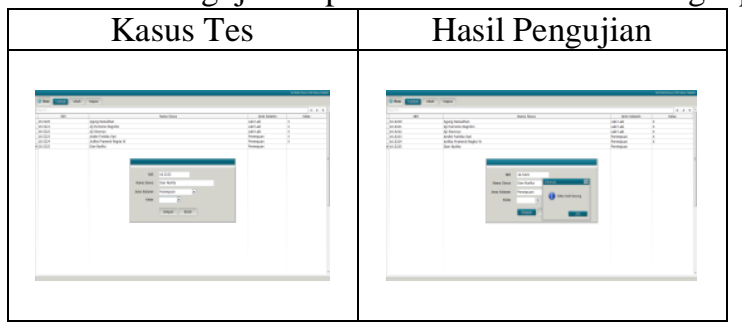

Pada pengujian input data siswa, dilakukan pengujian dengan mengisikan data siswa tidak lengkap, hasilnya yaitu sistem menampilkan pesan error. Oleh karena itu pengujian ini valid.

B. Input data siswa (field tidak ada yang kosong) lalu simpan. 
Hasil yang diharapkan pada pengujian ini yaitu sistem menampilkan list data siswa.

Tabel 6. Pengujian Input Data Siswa Dengan Benar

\begin{tabular}{|c|c|}
\hline Kasus Tes & Hasil Pengujian \\
\hline & \\
\hline
\end{tabular}

Hasil pengujian ini adalah valid, dimana sistem akan menampilan pesan data berhasil disimpan dan menampilkan data siswa terbaru.

C. Melakukan edit data siswa lalu simpan

Hasil yang diharapkan pada pengujian ini yaitu data siswa berhasil di edit dan akan menampilkan data yang baru.

Tabel 7. Pengujian Edit Data Siswa

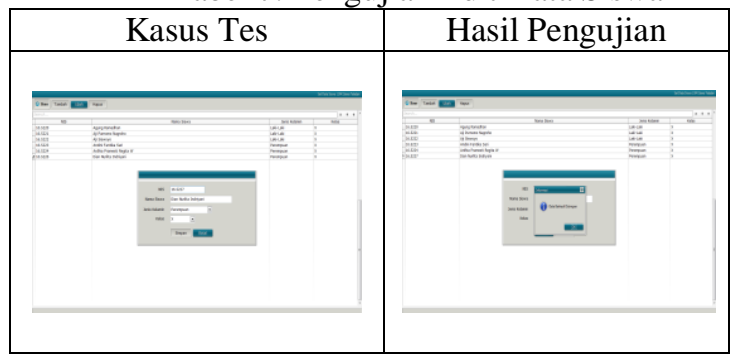

Hasil pengujian ini adalah valid, dimana sistem menampilkan data setelah berhasil diubah.

D. Melakukan hapus data siswa dengan klik tombol hapus

Hasil yang diharapkan pada pengujian ini yaitu data akan terhapus dan tidak tampil pada list data siswa.

Tabel 8. Pengujian Hapus Data Siswa

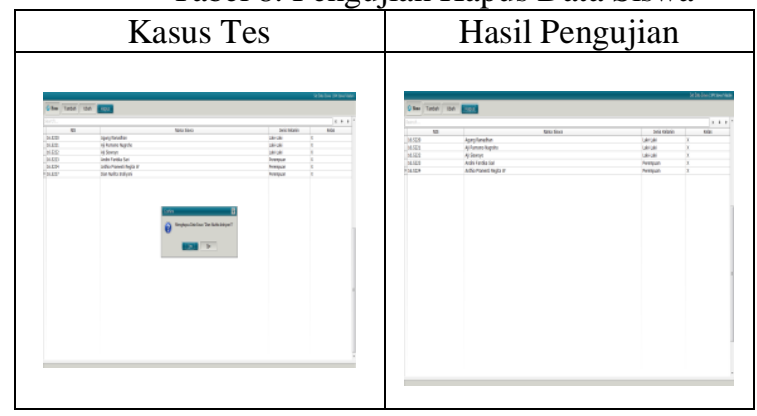

Pada pengujian ini sistem berhasil menghapus data, oleh karena itu pengujian ini valid.

\section{Kesimpulan}

Berdasarkan hasil dari penelitia ini, maka peneliti dapat mengambil beberapa kesimpulan, antara lainnya adalah seperti berikut ini:
1) Sistem informasi penentuan siswa berprestasi dapat dijadikan alat bantu di sekolah SMK Telkom Purwokerto dalam menentukan siswa berprestasi yang tepat sasaran karena penentuan siswa berprestasi tersebut dilakukan oleh sistem berbasis komputer yang bersifat objektif .

2) Dengan adanya sistem informasi penentuan siswa teladan, pihak sekolah bisa lebih mudah memilih kriteria-kriteria yang menjadi acuan penilaian siswa berprestasi, sehingga penilaian untuk menentukan siswa berprestasi tidak hanya satu aspek saja.

3) Untuk upaya memudahkan akses dalam pengelolaan, disarankan sistem informasi penentuan siswa berprestasi ini di hosting ke domain sekolah.

\section{DAFTAR PUSTAKA}

[1] J. N. Purwaningsih and Y. Suwarno, "Predicting students achievement based on motivation in vocational school using data mining approach," 2016 4th Int. Conf. Inf. Commun. Technol. ICoICT 2016, vol. 4, no. c, pp. 1-5, 2016.

[2] S. M. Siregar, "Sistem Pendukung Keputusan Pemilihan Guru Teladan Di SMA Era Utama Pancur Batu Menggunakan Metode TOPSIS," Pelita Inform. budi Darma, vol. IX, no. 2, pp. 76-84, 2015.

[3] K. W. Hipel and L. Fang, "The Graph Model for Conflict Resolution and Decision Support," IEEE Trans. Syst. Man, Cybern. Syst., vol. 51, no. 1, pp. 131141, 2021.

[4] D. Y. H. Tanjung and R. Adawiyah, "Optimizing Selection of Decision Support System with Fuzzy Simple Additive Weighting," 2018 6th Int. Conf. Cyber IT Serv. Manag. CITSM 2018, no. Citsm, pp. 7-10, 2019.

[5] I. Herman Firdaus, G. Abdillah, F. Renaldi, and U. Jenderal Achmad Yani J1, "Sistem Pendukung Keputusan Penentuan Karyawan Terbaik Menggunakan Metode Ahp Dan Topsis," Semin. Nas. Teknol. Inf. dan Komun., vol. 2016, no. Sentika, pp. 2089-9815, 2016.

[6] Y. Yamasari, S. M. S. Nugroho, I. N. Sukajaya, and M. H. Purnomo, "Features extraction to improve performance of clustering process on student achievement," 20th Int. Comput. Sci. Eng. Conf. Smart Ubiquitos Comput. Knowledge, ICSEC 2016, pp. 1-5, 2017.

[7] E. W. Perdani, A. Suryanto, R. D. M. P, and S. Sukamta, "Dengan Metode Simple Additive Weighting ( Saw )," vol. 1, no. 1, pp. 34-39, 2014.

[8] T. Mufizar, "Sistem Pendukung Keputusan Pemilihan Dosen Berprestasi Di STMIK Tasikmalaya Menggunakan Metode Simple Additive Weighting (SAW)," CSRID (Computer Sci. Res. Its Dev. Journal), 
vol. 7, no. 3, p. 155, 2016.

[9] M. Widyaningsih and L. Giovanni, "Penentuan Peserta Lomba Kompetensi Siswa Menggunakan Simple Additive Weighting (Saw)," JIKO (Jurnal Inform. dan Komputer), vol. 1, no. 1, 2016.

[10] K. Wang, "Design of big data intelligent sharing system for the creative achievement of college students in internet+ age," Proc. - 2019 Int. Conf. Robot. Intell. Syst. ICRIS 2019, no. 2, pp. 352-355, 2019.

[11] W. Hidayat, M. Ardiansyah, and K. Kusrini, "Decision Support System for Selection of Staples Food and Food Commodity Price Prediction Post-COVID-19 Using Simple Additive Weighting and Multiple Linear Regression Methods," 2020 3rd Int. Conf. Inf. Commun. Technol. ICOIACT 2020, pp. 45-50, 2020.

[12] Y. K. Kumarahadi, E. Apriliyanto, D. Yulianto, and Kusrini, "Decision Support System for Determining the Provision of Single Tuition Relief Using KNN and SAW Methods," 2020 8th Int. Conf. Cyber IT Serv. Manag. CITSM 2020, 2020.

[13] H. Kurniawan, A. P. Swondo, E. P. Sari, K. Ummi,
Yufrizal, and F. Agustin, "Decision Support System to Determine the Student Achievement Scholarship Recipients Using Fuzzy Multiple Attribute Decision Making (FMADM) with SAW," 2019 7th Int. Conf. Cyber IT Serv. Manag. CITSM 2019, pp. 3-8, 2019.

[14] F. N. Khasanah, R. Trias Handayanto, H. Herlawati, D. Thamrin, P. Prasojo, and E. S. H. Hutahaean, "Decision support system for student scholarship recipients using simple additive weighting method with sensitivity analysis," 2020 5th Int. Conf. Informatics Comput. ICIC 2020, no. 2, pp. 1-6, 2020.

[15] D. F. Murad, E. Fernando, A. W. More L, and R. C. Aulia, "Application engineer selection using simple additive weighting method approach," Proc. 2020 Int. Conf. Inf. Manag. Technol. ICIMTech 2020, no. August, pp. 660-663, 2020.

[16] D. D. Darmansah, "Perancangan Sistem Informasi Pengolahan Jadwal Mata Pelajaran Siswa Secara Online Di Smpn 31 Padang Berbasis Web," JATISI (Jurnal Tek. Inform. dan Sist. Informasi), vol. 7, no. 3, pp. 451-465, 2020. 